\title{
SEVERE MICROCYTIC ANAEMIA DUE TO CROHN'S DISEASE - AN UNCOMMON PRESENTATION
}

\author{
MD. ABUL KALAM AZAD ${ }^{1}$, MONZOOR QUADER ${ }^{2}$, MOHAMMAD FERDOUS UR RAHAMAN $^{2}$, MD ABDUR $^{2}$ \\ RAHIM $^{3}$, AKLIMA KHANAM ${ }^{4}$, NASEEB MOHAMMAD IRSHADULLAH ${ }^{4}$
}

\begin{abstract}
Crohn's disease is an uncommon disease. Most common presentation is abdominal pain, diarrhea and weight loss. It may present as subacute or even acute intestinal obstruction. Crohn's disease is very rare in Bangladesh. Here we report a case of Crohn's disease where the initial presentation was severe microcytic hypochromic anaemia. Who had repeated blood transfusion for one year. Initially cause was not detected. Later on he presented with subacute intestinal obstruction. After all diagnostic work up no definitive diagnosis could be found. So laparotomy was done in Bangabandhu Shiekh Mujib Medical University (BSMMU). Histopathology report was suggestive of Crohn's disease and he was on mesalazine with significant clinical improvement.
\end{abstract}

\section{Intrduction}

Inflammatory bowel diseases (IBD) are chronic inflammatory bowel disease. Two major forms of nonspecific IBD are recognized: Crohn's disease (CD), which can affect any part of the GI tract, and ulcerative colitis (UC), which affects only the large bowel. There is overlap between these two conditions in their clinical features, histological and radiological abnormalities; in $10 \%$ of cases of colitis a definitive diagnosis of either $\mathrm{UC}$ or $\mathrm{CD}$ is not possible. The incidence of $\mathrm{CD}$ varies from country to country but is approximately 4-10 per 100000 annually, with a prevalence of 27-106 per 100 000. It is very rare in developing country like Bangladesh. This disease is a multisystem disease which can affect any part of the body. The most common problem in diagnosing a case of Crohn's disease is similarity with tuberculosis. Its actually a diagnostic challenge to differentiate between disseminated TB.

In this particular case we present an isolated Crohn's disease that was initially presented with severe anemia.

\section{Case Report}

A 26-year-old married male was initially presented with profound asthenia two and half year back. For that he was evaluated and diagnosed as a case of severe anemia and was treated with seven unit of blood transfusion on two different occasion, but he lost all his documents. On that time, he had no history of haematemesis, melaena, jaundice, vomiting or bladder-bowel complaints. For the last one year he developed recurrent central abdominal pain. His pain was intermittent and moderate to severe in intensity, compelled to leave his job. He was admitted in BSMMU for further evaluation.

On admission he was severely anaemic, pulse 90/ min, BP $100 / 70 \mathrm{~mm}$ hg. There was no lymphadenopathy, bony tenderness, or organomegaly. He had mild tender abdomen with normal per rectal examination. Other systemic examination was also normal.

Investigation revealed $\mathrm{Hb}: 6.4 \mathrm{gm} / \mathrm{L}, \mathrm{MCV} 67 \mathrm{fL}, \mathrm{MCH}$ 20 pg, MCHC 290 g/L, RDW 18\%. Peripheral blood film showed microcytic hypochromic anaemia. He underwent extensive evaluation for iron deficiency anaemia after admission to BSMMU. Haemoglobin electrophoresis was normal. S ferritin was $7.13 \mu \mathrm{gm} /$ L, occult blood test was positive but upper GI endoscopy was normal. After 3 units of blood transfusion $\mathrm{Hb}$ level was $8.6 \mathrm{gm} / \mathrm{L}$, but after less than a month $\mathrm{Hb}$ level was again $5.2 \mathrm{gm} / \mathrm{L}$ with features consistent with iron deficiency anaemia. LFT and S Creatinine were normal. USG of the whole abdomen was also normal.

Radionuclide imaging for GI bleeding failed to show any site of GI bleeding. Barium follows through showed persistent and alternate narrowing \& dilatation of ileum. The terminal ileum, caecum, \& proximal ascending colon were narrow \& contracted consistent with granulomatous disease (Fig 1). He

1. Associate Professor, Department of Medicine, BSMMU.

2. Medical Officer, Department of Medicine, BSMMU.

3. Professor, Department of Medicine, BSMMU.

4. Resident, Department of Haematology, BSMMU.

Bangladesh J Medicine 2010; 21 : 101-104 
developed acute abdomen and we failed to do colonoscopy. He was referred to surgery department and underwent laparotomy on $2^{\text {nd }}$ March 2011.

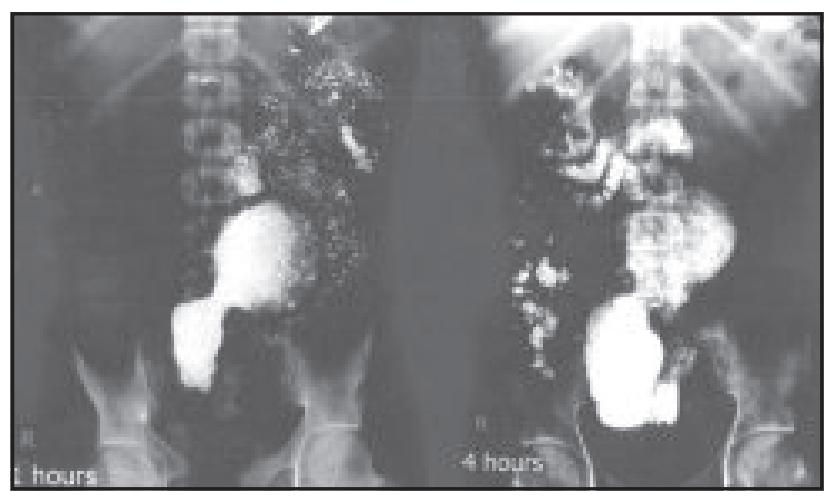

Fig.-1: Alternate narrowing and dilatation of Ileum

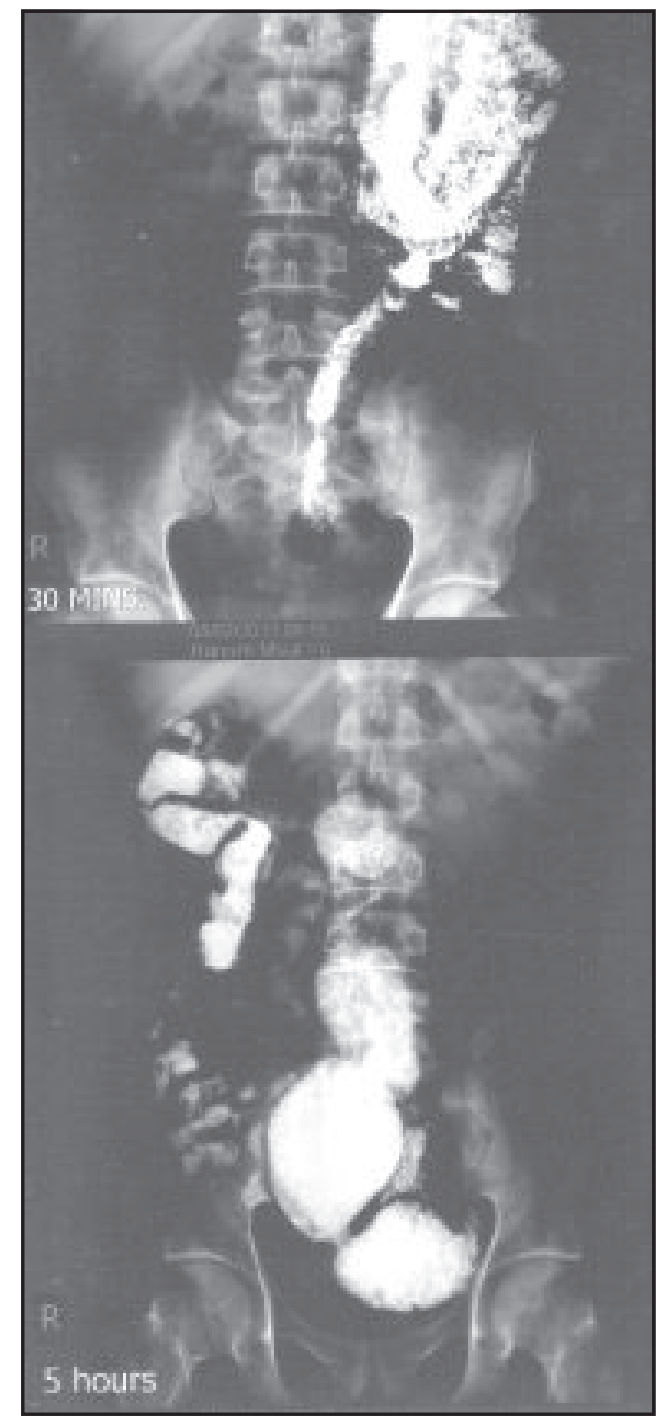

Fig.-2: Narrowing of the Jejunum \& Ileum

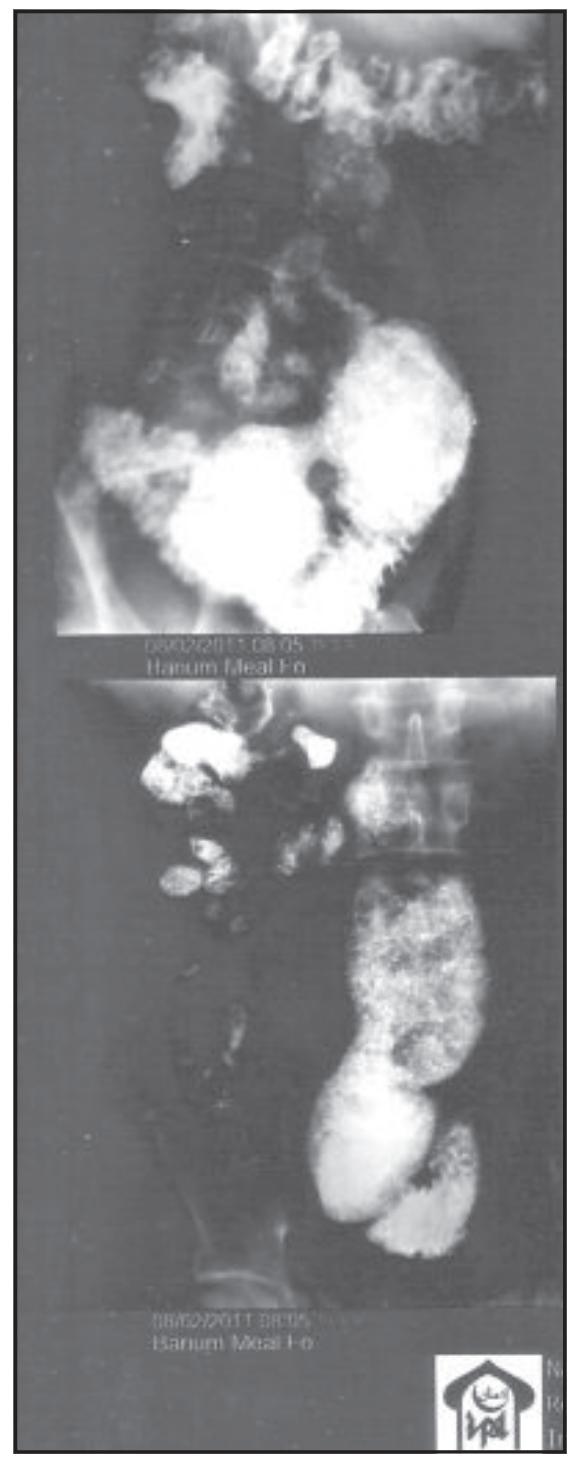

Fig.-3: Terminal Ileum, caecum and a ascending colon narrowed \& contracted

During laparotomy multiple strictures with an ileoileal internal fistula was found. Proximal ileum was distended with collapsed distal part. Multiple congenital bands and adhesions were also noted within the different portions of ileum. Multiple mesenteric lymphadenopathies were seen. Adhesionolysis, resection with ileo-ileal anastomosis was done. Histopathology of the resected ileum showed multiple ulcers lined by granulation tissue overlying the pseudopyloric metaplasia; lining areas shows goblet cell depletion; submucosa shows smooth muscle proliferation; transmural inflammation is also noted; features consistent with Crohn's disease. 


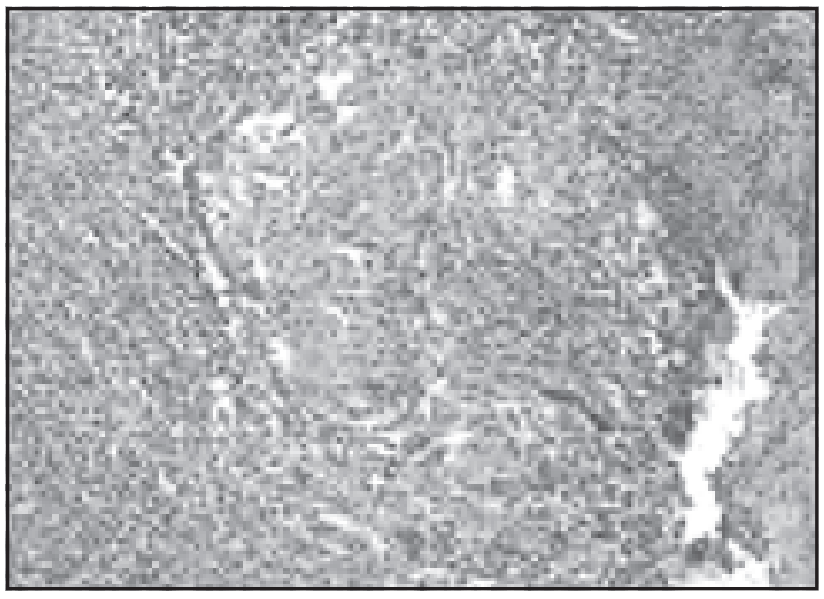

Fig.-4: Histopathology of resected ileum

With this finding he was diagnosed as a case of Crohn's disease. He is on mesalazine $1600 \mathrm{mg} /$ day with significant clinical improvement.

\section{Discussion}

Crohn's disease is a multisystem disease. Most to the cases patient present with abdominal symptoms such as abdominal pain, alteration of bowel habit, haematemesis, meleana, and also extraintestinal symptoms such as joint pain redness of eye, skin lesion etc. But this patient presented with unexplained iron deficiency anaemia. In most patients with $\mathrm{CD}$, anemia is due to gastrointestinal blood loss and chronic inflammation. But there are other causes which should be kept in the list such as autoimmune hemolytic anaemia (AHA). The difference in the incidence of AHA between ulcerative colitis and $C D$ has been frequently noted. For diagnosis of this patient we had extensive workup. At the end we went for surgery. The biopsy confirmed as CD. After confirmation of the diagnosis he was initially started with I/V methylprednisolone. Now the patient is quite settled we are maintaining with aminosalisylates.

\section{Consent}

Written informed consent was obtained from the patient for publication of this case report and accompanying images. A copy of the written consent is available for review by the Editor-in-Chief of this journal.

\section{Competing Interest}

The authors declare that they do not have any competing interests.

\section{References}

1. Singh V, Kumar P, Kamal J, Prakash V, Vaiphei K, Singh K. Clinicocolonoscopic profile of colonic tuberculosis. Am J Gastroenterol. 1996; 91:565-568.

2. Probert CSJ, Jayanti V, Wicks AC, Carr-Locke DL, Mayberry JF. Epidemiological study of abdominal tuberculosis among Indian migrants and the indigenous population of Leicester, 1972-1989. Gut. 1992; 33:1085-1088.

3. Chen WS, Leu SY, Hsu H, Lin JK, Lin TC. Trend of large bowel tuberculosis and the relation with pulmonary tuberculosis. Dis Colon Rectum. 1992; 35:189-192.

4. Guth A, Kim U. The reappearence of abdominal tuberculosis. Surg Gynecol Obstet. 1991; 172:432436.

5. Palmer KB, Patil DH, Basran GS, Riordan JF, Silk DB. Abdominal tuberculosis in urban Britain. A common disease. Gut. 1985; 26:1296-1305.

6. Watson JM, Gill ON. HIV infection and tuberculosis: Br Med J. 1990; 300:63-65.

7. Marshall JB. Tuberculosis of the gastrointestinal tract and peritoneum. Am JGastroenterol. 1993; 88:989-999.

8. Snider Jr DE, Roper WL. The new tuberculosis. N Eng J Med. 1992; 326:703-705.

9. McGee GS, Williams LF, Potts J, Barnwell S, Sawyers JL. Gastrointestinal tuberculosis: resurgence of an old pathogen. Am Surg. 1989; 55:16-20.

10. Arnold C, Moradpour D, Blum HE. Tuberculous colitis mimicking Crohn's disease. Am J Gastroenterol. 1998; 11:2294-2296. doi: 10.1016/ S0002-9270(98)00525-5.

11. Kaushik SP, Bassett ML, McDonald C, Lin BP, Bokey EL. Case report: gastrointestinal tuberculosis simulating Crohn's disease. J Gastroenterol Hepatol. 1996; 11:532-534.

12. Klimach OE, Ormerod LP. Gastrointestinal tuberculosis: A retrospective review of 109 cases in a district general hospital. Q J Med. 1985; 56:56978 .

13. Sherman S, Rohwedder JJ, Ravikrishann KP, Weg JG. Tuberculous enteritis and peritonitis. Report of 36 general hospital cases. Arch Intern Med. 1980; 140:506-508. doi: 10.1001/archinte.140.4.506.

14. Jakubowski A, Elwood RK, Enarson DA. Clinical features of abdominal tuberculosis. J Infect Dis. 1988; 158:687-692.

15. Shah S, Thomas V, Mathan M, Chacko A, Chandy G, Ramakrishna BS, Rolston DDK. Colonoscopic study of 50 patients with colonic tuberculosis. Gut. 1992; 33:347-351. 
16. Al Karawi MA, Mohamed AE, Yasawy ML, Graham DY, Shariq S, Ahmed AM, Al Jumah A, Ghandour $Z$. Protean manifestations of gastrointestinal tuberculosis. Report of 130 patients. J Clin Gastroenterol. 1995; 20:225-232.

17. Misra SP, Misra V, Dwivedi M, Gupta SC. Colonic tuberculosis: clinical features, endoscopic appearance and management. J Gastroenterol Hepatol. 1999; 14:723-729. doi: 10.1046/j.14401746.1999.01940.x.

18. Anand BS, Schneider FE, El-Zaatari FAK, Shawar RM, Clarridge JE, Graham DY. Diagnosis of intestinal tuberculosis by polymerase chain reaction on endoscopic biopsy specimens. Am J Gastroenterol. 1994; 89:2248-2249.

19. Bhargava DK, Dasarathy S, Shriniwas MD, Kushwaha AK, Duphare H, Kapur BM. Evaluation of enzyme-linked immunosorbent assay using mycobacterial saline-extracted antigen for the serodiagnosis of abdominal tuberculosis. Am J Gastroenterol. 1992; 87:105-108.

20. Balthazar EJ, Gordon R, Hulnick D. Ileocecal tuberculosis: CT and radiologic evaluation. Am J Roentgenol. 1990; 154:499-503.

21. Ferentzi CV, Sieck JO, Ali MA. Colonoscopic diagnosis and medical treatment of ten patients with colonic tuberculosis. Endoscopy. 1988; 20:62-65. 